\title{
Epigenetic Characterization of the CpG Islands of Bovine Leptin and POU5F1 Genes in Cloned Bovine Fetuses
}

\author{
Maksym KREMENSKOY'), Yuliya KREMENSKA ${ }^{1)}$, Masako SUZUKI'), Kei IMAI'), \\ Seiya TAKAHASHI ${ }^{3)}$, Kazuyoshi HASHIZUME), Shintaro YAGI ${ }^{1)}$ and \\ Kunio SHIOTA ${ }^{1)}$
}

1) Laboratory of Cellular Biochemistry, Animal Resource Science/Veterinary Medical Sciences, Graduate School of Agricultural and Life Sciences, The University of Tokyo, 1-1-1 Yayoi, Bunkyo-ku, Tokyo 113-8657, ${ }^{2}$ Department of Technology, National Livestock Breeding Center, 1 Odakurahara, Odakura, Nishigo, Fukushima 961-8511, ${ }^{3)}$ Reproductive Cell Biology Laboratory, Department of Animal Breeding and Reproduction, National Institute of Livestock and Grassland Science, 2 Ikenodai, Tsukuba, Ibaraki 305-0901, ${ }^{4}$ Laboratory of Veterinary Physiology, Department of Veterinary Medicine, Faculty of Agriculture, Iwate University, 318-8 Ueda, Morioka, Iwate 020-8550, Japan

\begin{abstract}
Abnormal development and fetal loss during postimplantation period are concerns for production of nuclear transferred animals. Aberrant DNA methylation is one of the reasons for poor survival of cloned animals. In mammalian genome DNA, CpG islands are preferentially located at the start of transcription of housekeeping genes and are associated with tissue-specific genes. The correct and consecutive mechanisms of DNA methylation in the $\mathrm{CpG}$ islands are necessary for selective gene expressions that determine the properties of individual cells, tissues, and organs. In this study, we investigated the methylation status of the CPG islands of the bovine Leptin and POU5F1 genes in fetal and placental tissues from fetuses produced by artificial insemination (AI) and nuclear transfer (NT) at days 48 and 59 of pregnancy. Altered DNA methylation was observed in the normal and cloned fetal, placental, and endometrial tissues using bisulfite sequencing and pyrosequencing. Different tissue-specific methylated regions in the bovine Leptin and POU5F1 genes show a variable methylation status in NT fetuses compared to AI control.

Key words: Bovine, CpG islands, DNA methylation, Leptin, Nuclear transfer, POU5F1
\end{abstract}

(J. Reprod. Dev. 52: 277-285, 2006)

D NA methylation is involved in the development of mammals through various gene functions, including gene-silencing, $X$ inactivation, and imprinting. DNA methylation occurs mainly at the cytosine in $\mathrm{CpG}$ dinucleotides. $\mathrm{CpG}$ islands are the stretches of the DNA sequence (over $200 \mathrm{bp}$ ) with higher CG contents (C+G

Accepted for publication: December 26, 2005

Published online: February 10, 2006

Correspondence: K. Shiota

(e-mail: ashiota@mail.ecc.u-tokyo.ac.jp) frequency; \%CG>50\%) and higher CpG frequencies with a ratio of observed to expected based on CpG content ( $\left.\mathrm{CpG}_{\mathrm{obs}} / \mathrm{CpG}_{\text {exp }}\right)$ over 0.6 [1]. Many housekeeping genes and almost half of the tissuespecific genes have $\mathrm{CpG}$ islands $[2,3]$. CpG islands and genes with regions of higher $\mathrm{CpG}$ frequencies were once considered to be unmethylated in all tissues except for those related to $X$ inactivation, genomic imprinting, and cancer $[4,5]$. However, there are tissue-dependent and differentially 
methylated regions (T-DMRs) even in CpG-rich unique sequences in rat and murine normal tissues and cells [6-9]. The human genome also shows DNA methylation in the CPG-rich regions of normal tissues $[10,11]$.

Production rate of cloned animals, which are obtained by transferring nuclei from adult somatic cells, is quite low due to early death after implantation, although production has been successful in several species [12-15]. We previously found that there are several loci with aberrant DNA methylation in fully developed cloned mice [16]. CpG islands associated with TDMRs are widespread in the mammalian genome [17], and their DNA methylation status illustrates the genome-wide profile unique to distinct cell types and tissues [6-8]. Since proper formation of DNA methylation profiles underlies normal differentiation and development, diagnosis based on determination of methylation profiles would be useful for evaluating the development of nuclear transferred (NT) animals.

T-DMRs in the CpG islands have been investigated in the mouse, rat, and human genome, but not in the bovine genome. Leptin is involved in regulation of interaction between maternal and fetoplacental compartments, and plays a functional role in fetal and placental growth [18]. POU5F1 encodes octamer-binding transcription factor 4, which is involved in the development of animals. In the present study, we characterized the CpG islands of the bovine Leptin and POU5F1 genes in normal bovine fetuses, and compared their DNA methylation status with those of cloned fetal and placental tissues.

\section{Materials and Methods}

\section{NT and control animals}

Bovine NT embryos were produced as described previously by using cumulus cells as the donor cells [19]. Control pregnancies were derived by artificial insemination (AI) of Japanese black cows (day $0=$ day of insemination). Diagnosis of pregnancy was made from days 30 of gestation by transrectal ultrasonography $(7.5 \mathrm{MHz}$ linear probe, SSD-1700, Aloka, Tokyo, Japan). Viability of fetuses was confirmed by detectable heartbeat 2-3 days prior to slaughter. NT and AI cows were slaughtered around days 48 and 59 of gestation.
The endometrial (caruncular and intercaruncular) and placental tissues (cotyledonary and intercolyledonary) from two control and two cloned animals were collected and separated as detailed by Nikitenko et al. [20]. Also, fetal brains were collected, and all tissues were immediately placed in liquid nitrogen and stored at $-80 \mathrm{C}$ till processing. (Fig. 1, Table 1).

\section{Preparation of genomic DNA}

Genomic DNA was extracted as described previously [6]. Briefly, cells and tissues were suspended in lysis buffer (10 mM Tris-HCl, $\mathrm{pH} 8.0$, 150 mM EDTA, 1\% SDS) with proteinase K (Merck, Darmstadt, Germany). The mixture was incubated at $55 \mathrm{C}$ for $20 \mathrm{~min}$. Following two phenol/ chloroform/isoamyl alcohol (50:49:1) extractions, the genomic DNA was precipitated in ethanol, pelletted, and redissolved in TE buffer (10 mM Tris$\mathrm{HCl}$, pH 7.6, 1 mM EDTA).

\section{Analysis of Cp G frequency}

The bovine Leptin and POU5F1 gene sequences were obtained from the NCBI database (AB070368 and AF022986) (http://www.ncbi.nlm.nih.gov). The structures of these genes were described previously [21,22]. The CG content and CpG frequency of the DNA sequences of these genes were analyzed by CpG View (version 1.4.6) on a Macintosh computer.

\section{Bisulfite modification of DNA and sequencing}

Genomic DNA digested with PstI was denatured by adding $0.3 \mathrm{M} \mathrm{NaOH}$ and incubated for $15 \mathrm{~min}$ at 37 C. After incubation, sodium metabisulfite $(\mathrm{pH}$ 5.0) and hydroquinone were added to final concentrations of $2.0 \mathrm{M}$ and $0.5 \mathrm{mM}$, respectively, and the mixture was further incubated at $55 \mathrm{C}$ for $14 \mathrm{~h}$ in darkness. The modified DNA was purified using the Wizard DNA Clean-Up System (Promega, Madison, WI), and the bisulfite reaction was terminated by 15 min incubation at $37 \mathrm{C}$ in 0.3 $\mathrm{M} \mathrm{NaOH}$. The solution was then neutralized by adding ammonium acetate $(\mathrm{pH} 7.0)$ to a final concentration of $3 \mathrm{M}$. The ethanol-precipitated DNA was resuspended in water and amplified by PCR using primers designed as follows: B_Lept_BS2_F, 5'-GAGGATTTTTTATATTTGTTTAGTT-3'; B_Lept_BS2_R, 5'-TAAACTAAATAACCTACCAAAAAAA-3'; POU5F1_BSpr_F, 5' TTTTTATTTTTGGTGTATGTGGGTT-3'; and 
A

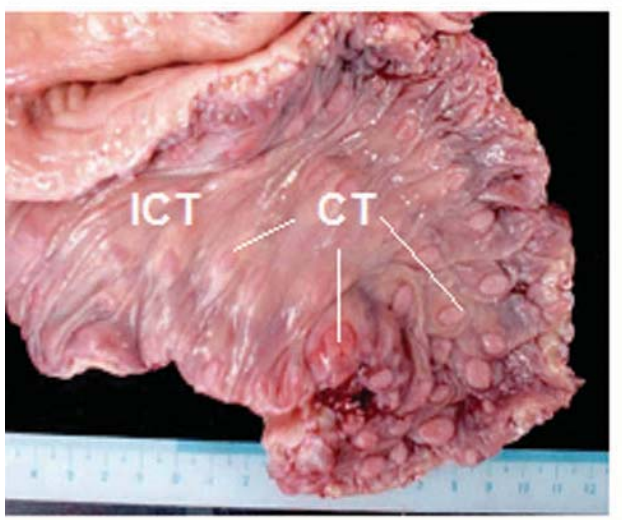

B

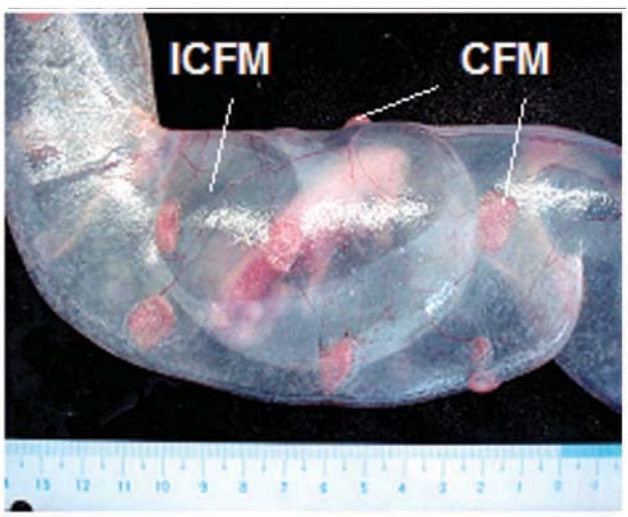

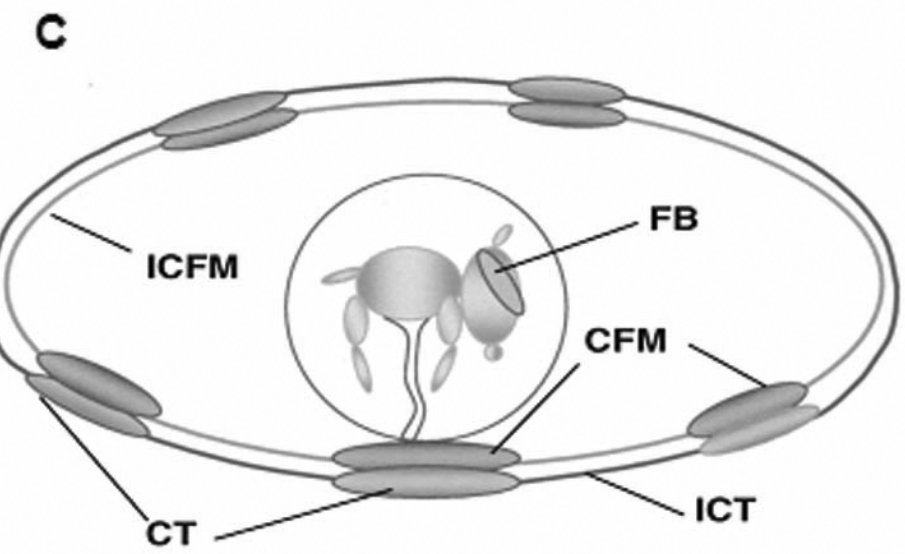

Fig. 1. (A and B) Pictures of bovine maternal and fetal parts of the placenta containing a control fetus on day 59 of pregnancy (scale in centimeters). (C) Schematic view of fetal-maternal interaction in bovine uterus. In cattle, maternal (intercaruncular tissue: ICT) and fetal (ICFM: intercotyledonal fetal membrane) tissues fuse in discrete areas forming a disc-shaped placentome that consists of a fetal component (cotyledonal fetal membrane: CFM) and a maternal component (carunculoular tissue: CT). FB: fetal brain.

Table 1. Samples used for study methylation status of the bovine Leptin and POU5F1 genes

\begin{tabular}{|c|c|c|c|c|c|}
\hline & & & Leptin gene & $\mathrm{POU}$ & ene \\
\hline & & Days & Bisulfite sequencing & Pyrosequencing & Bisulfite sequencing \\
\hline Control & $\# 1$ & 48 & & & \\
\hline & \#2 & 59 & & & \\
\hline Clone & $\# 1$ & 48 & ICFM, FB & ICFM, CFM, FB, CT & ICFM, FB \\
\hline & \#2 & 59 & & & \\
\hline
\end{tabular}

POU5F1_BSpr_R, 5'-AAAAACCCTTAAAAACTCATCCAAA-3'.

PCR amplification was performed with $10 \mathrm{ng}$ of bisulfite-converted DNA in a total reaction volume of $50 \mu \mathrm{l}$ using Immolase DNA polymerase (Bioline, London, UK). The PCR conditions were as follows
: $95 \mathrm{C}$ for $10 \mathrm{~min} ; 40$ cycles of $94 \mathrm{C}$ for $30 \mathrm{sec}, 55 \mathrm{C}$ for $30 \mathrm{sec}$, and $72 \mathrm{C}$ for $60 \mathrm{sec}$; and final extension 72 $\mathrm{C}$ for $10 \mathrm{~min}$. Amplified PCR products were cloned into pGEM-T easy vector (Promega, Madison). Individual clones were sequenced using an ABI Prism 310 sequencer (Genetic Analyzer). 
Table 2. Primers for pyrosequencing analysis of the bovine POU5F1 gene

\begin{tabular}{|c|c|c|c|c|}
\hline Region & PCR primers & Length & Sequencing primers & CpG\# \\
\hline \multirow[t]{4}{*}{ Region I } & POU5F1_BS2_F (Forward) & 541 & 5'-GAAGTGTTAGTTATGTT-3' & 1 \\
\hline & 5'-ATGGAAGTTGGTTTGGTAGTTTGTT-3' & & 5'-TTGATTTATAGATTGTAGTT-3' & 2,3 \\
\hline & POU5F1_BS_R (Reverse) & & 5'-AGGTAAGTATATTGGAGT-3' & 4 \\
\hline & 5'-СТССССАААСССАСАТАСАССАААA-3' & & 5'-GGGGTTTTGAATAA-3' & 6 \\
\hline \multirow[t]{5}{*}{ Region II } & POU5F1_BSpr_F (Forward) & 474 & 5'-TTGGAAGTGAAGGT-3' & 8 \\
\hline & 5'-TTTTTATTTTTGGTGTATGTGGGTT-3' & & 5'-CСАААСТССТАААСТ-3' & 9 \\
\hline & POU5F1_BSpr_R (Reverse) & & 5'-AAATATTTACСТАСТАATAA-3' & 10 \\
\hline & 5'-АААААСССТТАААААСТСАТССААА-3' & & 5'-TATTAGTAGGTAAATATTTT-3' & 11 \\
\hline & & & 5'-АССТТААССТСТААС-3' & 13 \\
\hline
\end{tabular}

\section{Pyrosequencing}

Bisulfite-treated genomic DNA was amplified by PCR with primers for the POU5F1 gene promoter region (Table 2). One of the PCR primers was biotinylated in order to create a single-stranded DNA template. The PCR conditions were the same as for bisulfite sequencing PCR. Purification of the PCR products with streptavidin sepharose HP beads (Amersham Biosciences Ab, Uppsala, Sweden) was conducted according to the manufacture's instructions. After completion of primer annealing, $500 \mathrm{ng}$ of single-strand DNAbinding protein (Sigma, St Louis, MO) was added to the sequencing reaction mix. Sequencing was performed on a PSQ 96MA system with a SNP reagent kit (Pyrosequencing, Uppsala, Sweden) according to the manufacturer's instructions. The raw data were analyzed using the allele quantitation algorithm of the provided software.

\section{Results}

DNA methylation status of the Leptin gene in cloned bovine embryos

Bovine Leptin gene contains a CpG island with a length of $282 \mathrm{bp}$ that spans from $-204 \mathrm{bp}$ to $+78 \mathrm{bp}$ and a $C G$ frequency and $\mathrm{CpG}_{\mathrm{obs}} / \mathrm{CpG}_{\exp }$ of $66 \%$ and 0.716 , respectively. We investigated a $367 \mathrm{bp}$-long fragment carrying this $\mathrm{CpG}$ island that contained 35 CpGs (Fig. 2A) by sodium bisulfite sequencing (Fig. 2B).

In the control animals, all CpGs were almost completely unmethylated in both the intercotyledonal fetal membrane (ICFM) and fetal brain (FB). Thus, the CpG island of the Leptin gene may serve as methylation free area in these bovine fetal tissues. In clones \#1 and \#2, the CpGs in the $\mathrm{CpG}$ island were also unmethylated in the ICFM, suggesting that the animal cloning process by nuclear transfer did not disturb normal DNA methylation in ICFM. Intriguingly, however, there was a different DNA methylation status in the CpG island of the FBs of the cloned animals. In clone \#1, the CpGs at the $5^{\prime}$-end of $\mathrm{CpG}$ island, the 3rd CpG (-195 bp), and the 4th CpG (-186 bp) showed moderate methylation (Fig. 2B). Similarly, the 3rd and 22nd CpGs showed methylation in clone \#2. At the 3 '-end of the studied CpG island fragment, there was abnormal methylation of $\mathrm{CpGs}$ at the $+44,+67$, and +70 bp (33rd, 34th, and 35th CpGs, respectively) in the FBs of clones \#1 and \#2. Therefore, abnormal DNA methylation occurred in the cloned animals depending on the tissue.

\section{DNA methylation of the POU5F1 gene in cloned bovine embryos}

Bovine POU5F1 gene also has a CpG island with a length of $189 \mathrm{bp}$ that spans from $-44 \mathrm{bp}$ to +145 $\mathrm{bp}$, a CG frequency of $72 \%$, and a $\mathrm{CpG}_{\text {obs }} / \mathrm{CpG}_{\mathrm{exp}}$ of 0.654 . There are $11 \mathrm{CpGs}$ arranged in the transcription start site and $3 \mathrm{CpGs}$ in the upstream region covering the $\mathrm{CpG}$ island. The region further upstream of the bovine POU5F1 gene is CpG poor, containing $13 \mathrm{CpGs}$ within $-815 \mathrm{bp}$ and a SINE sequence from -578 bp to $-762 \mathrm{bp}$ with $4 \mathrm{CpGs}$ (Fig. 3A).

We investigated 10 CpGs $(1,2,3,4,6,8,9,10,11$, and 13$)$ in the $5^{\prime}$-upstream region of the bovine POU5F1 gene in caruncular tissue (CT) and cotyledonal fetal membranes (CFM) by pyrosequencing analysis following the bisulfite 


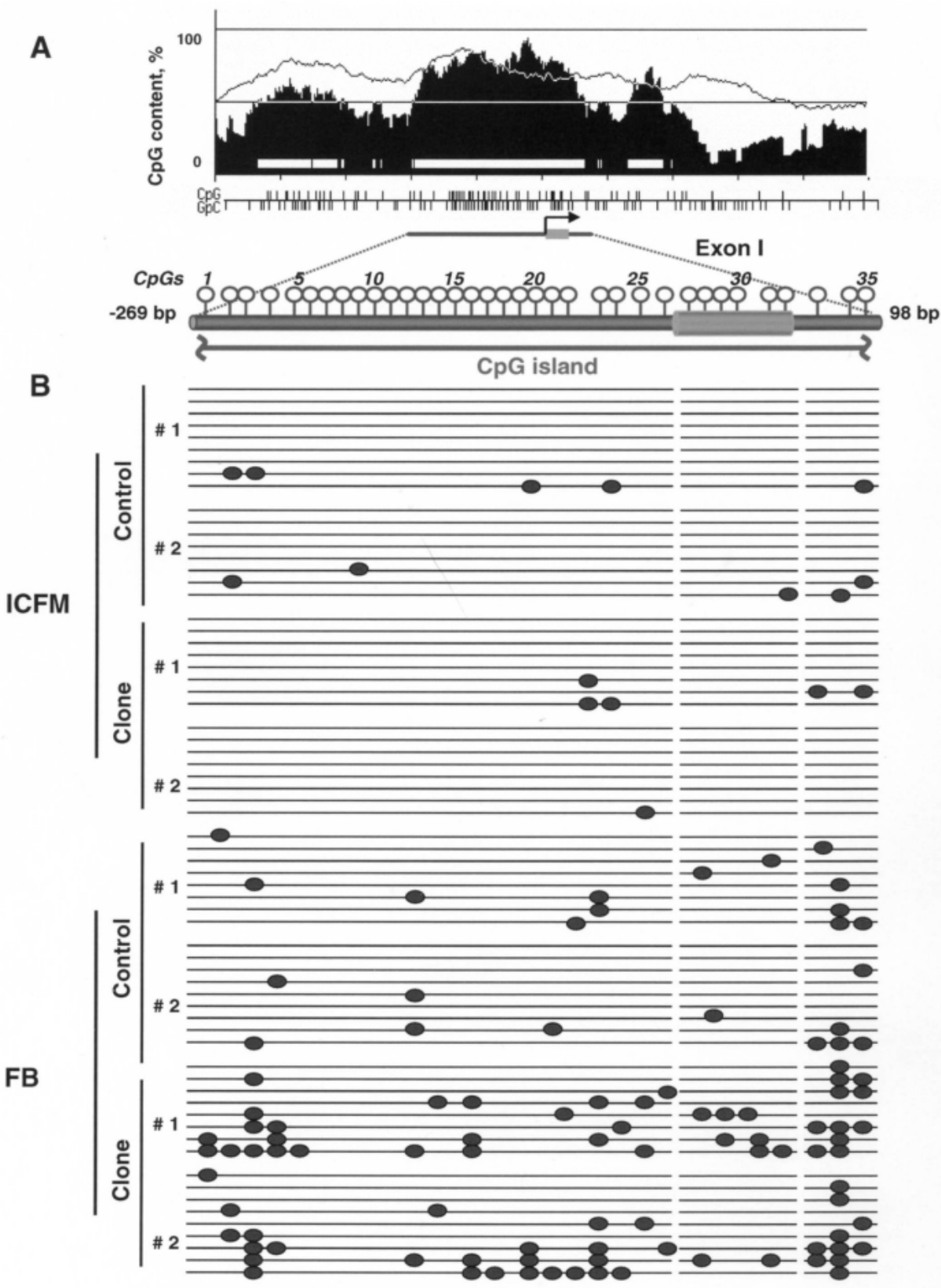

Fig. 2. DNA methylation status of the $5^{\prime}$ flanking region and 1st exon of the bovine Leptin gene in fetal tissues of NT and AI animals. (A) The upper panel shows the GC content and CpG frequency of the bovine Leptin gene ( $-500 \mathrm{bp}$ to $+500 \mathrm{bp}$ ). The jagged line represents the average GC content, and the black bar displays the CpG frequency. White boxes represent $\mathrm{CpG}$ rich regions. The middle bars show the positions of the $\mathrm{CpG}$ and $\mathrm{GpC}$ sites. A schematic view of the region $(-269 \mathrm{bp}$ to $+98 \mathrm{bp})$ analyzed by sodium bisulfite sequencing is shown in the lower panel. Open circles display the CpG positions. (B) The DNA methylation status of each PCR clone was determined by sodium bisulfite sequencing method. Black circles display the methylated status of the CpG sites.

treatment (Fig. 3B). The analysis revealed that the methylation levels of almost all of the CpGs in CT were higher than those in the ICM. As an example, most of the 8th CpG at -281 bp was methylated in the CT $(90.1 \%)$ of control \#1, whereas the methylation degree was comparatively low in the CFM (57\%). The degree of methylation was $50 \%$ in the 6th CpG at -506 bp in the CTs, but $0 \%$ in the 
(A)

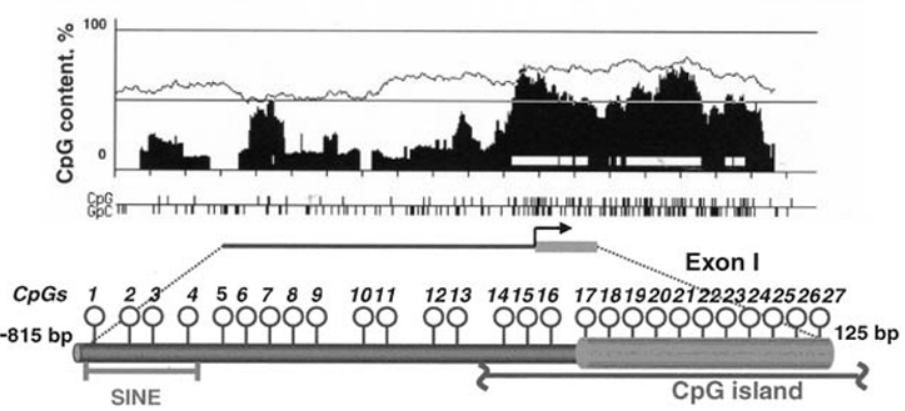

(B)

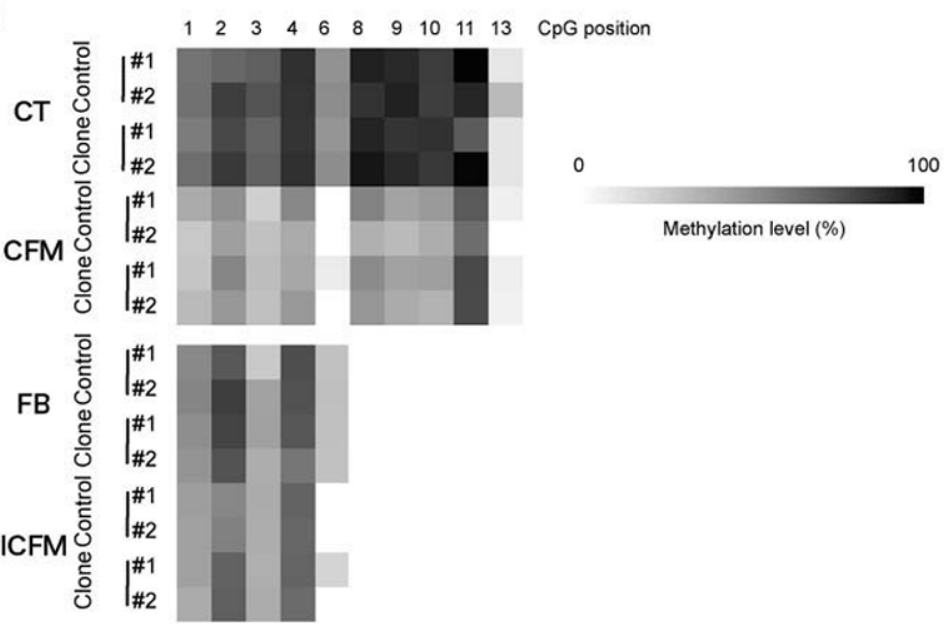

(C)

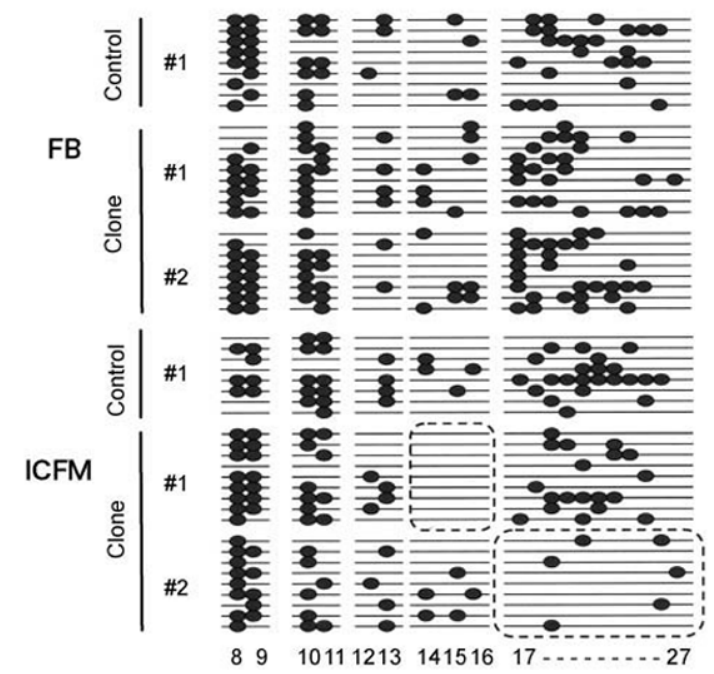

Fig. 3. DNA methylation analysis of the bovine POU5F1 gene promoter region and first exon. (A) The upper panel shows the GC content and CpG frequency of bovine POU5F1 gene ( $-1145 \mathrm{bp}$ to $+766 \mathrm{bp})$. The jagged line represents the average GC content, and the black bar displays CpG frequency. White boxes represent $\mathrm{CpG}$ rich regions. The middle bars show the positions of the $\mathrm{CpG}$ and $\mathrm{GpC}$ sites. Open circles display the $\mathrm{CpG}$ positions. (B) Pyrosequencing analysis data for the 1st to 10th CPG in the promoter region of the bovine POU5F1 gene in the CT and CFM. Each methylation level for the 1st to 6th CpG in the FB and ICFM was also analyzed by pyrosequencing. The methylation level of each $\mathrm{CpG}$ is represented by a gray scale (right side of the figure). (C) Bisulfite sequencing of $20 \mathrm{CpGs}$ (from 8th to 27th) arranged in the promoter region (9 CpGs) and 1-st exon (11 CpGs) of the bovine POU5F1 gene. The 14th, 15th and 16th CpGs were completely unmethylated in the ICFM of clone \#1 and are enclosed by a dotted line while the ICFMs of the controls and clone \#2 showed partial methylation. Furthermore, the CpGs of the 1st exon have a lower methylation level in the ICFM clone \#2 (enclosed by with dotted line) compared to that of the controls and clone \#1. 
CFMs of control \#1 and \#2. Thus, the 6th CpG displayed a clear difference between the $\mathrm{CT}$ and CFM. In addition, the 4th, 8th, 9th, and 10th CpGs displayed methylation of more than $80 \%$ in the CT, whereas they displayed about $50 \%$ methylation in the CFM (Fig. 3B). Therefore, the region containing the 1st to 11th CpGs was T-DMR.

The pyrosequencing data of the 1st to 6th CpGs in the FBs and ICFMs confirmed the conclusion above. The DNA methylation levels of most CpGs in the FBs and ICFMs were less than those in the CTs. The profiles of the DNA methylation levels in these CpGs were different among these tissues.

The 6th CpG displayed difference in methylation status between clone \#1 (9.5\%) and the controls $(0 \%)$ in the CFM. The methylation status of the 6 th CpG was $0 \%$ in the ICFMs of controls \#1 and \#2. In clone \#1, however, this CpG showed 20.7\% methylation in the ICFM. Similarly, the methylation status of the 6th CpG was slightly different in the CFM of clone \#1 compared to control. These data illustrated the locus of $\mathrm{CpG}$ in the bovine POU5F1 gene with an epigenetic variation between clones and controls.

Another region with epigenetic variations in cloned animals was identified by authentic bisulfite sequencing of $20 \mathrm{CpGs}$ in ICFMs and FBs (Fig. 3C). In the ICFM of clone \#1, the 14th, 15th, and 16th CpGs were completely unmethylated, whereas they were moderately methylated in the control. Furthermore, in the ICFM of clone \#2, the 1st exon CpGs were unmethylated in contrast to the other ICFMs. No such difference was observed in the FBs.

\section{Discussion}

Many genes have T-DMRs and the DNA methylation profiles of T-DMRs are involved in tissue-specific and developmentally regulated gene expression [23]. Leptin is expressed in placenta and it may have physiological effects on placental growth. Abnormal placental leptin production associated with increased trophoblast proliferation [24] and the leptin concentration in cord blood are positively correlated with placental size [25]. Ravelich et al. [26] showed increased Leptin mRNA expression in the placenta of NT pregnancies. Yokomori et al. [27] demonstrated changes in DNA methylation in the promoter region of the Leptin gene in mouse 3T3-L1 cells during differentiation, suggesting that DNA methylation is involved in Leptin gene expression. In bovine NT pregnancies, altered feto-placental growth and function is associated with disturbance in Leptin expression, which could lead to inadequate placentation [26]. The cloned fetuses (\#1 and \#2) in the present study were fortunate to have a normal methylation status for the T-DMR of the bovine Leptin gene in the ICFM. It is important to note that abnormal methylation of the ICFM has the potential to disrupt placental development and function.

In addition to its physiological effects on placental growth, leptin is also important for fetal development because it regulates the metabolic adaptation during fetal development that is required for normal pregnancy [28]. Abnormal methylation of the Leptin gene was detected in the FBs of the cloned fetuses, and thus may disturb further normal development of the brains of the cloned animals.

Several reports have revealed abnormal DNA methylation in preimplantation cloned embryos [29-31]. Since a large part of the genome is composed of non-genic repetitive elements [32, 33] the overall level of DNA methylation reflects the bulk methylation status of these repetitive sequences rather than unique sequences of the genes. Therefore, careful discussion of the genic and non-genic elements is required. DNA methylation of $\mathrm{CpG}$ islands is involved in regulation of tissue-specific gene expression [7]. Therefore, aberrant DNA methylation at $\mathrm{CpG}$ islands has the potential to have a deleterious effect on the phenotypes of cloned animals. The organization of bovine POU5F1 is similar to its human and murine orthologs. Hattori et al. [34] showed that in mice, Oct-4 gene expression is under the regulation of DNA methylation and chromatin structure remodeling. The bovine POU5F1 expression pattern could be detected in early bovine embryonic development, but was not restricted to the pluripotent cells of the blastocyst [22]. There was no significant difference in DNA methylation patterns at the $\mathrm{CpG}$ island of the POU5F1 gene between normal controls and cloned fetuses. Taking this together with the fact that the methylation status of Leptin gene in the ICFMs of the clones was similar to that of the normal control ICFMs, our data generally suggests that the extent of the abnormal DNA methylation profile is not 
severe in cloned bovine fetus that are allowed to develop until 48 and 59 days.

Characterizing the gene associated with $\mathrm{CpG}$ islands is necessary to evaluate the development of normal and cloned cows. To our knowledge, this is the first report on the $\mathrm{CpG}$ islands of bovine genes. There are T-DMRs in the bovine POU5F1 and Leptin genes that show a variable methylation status in cloned bovine fetuses compared to normal controls.

\section{References}

1. Takai D, Jones PA. Comprehensive analysis of CpG islands in human chromosomes 21 and 22. Proc Natl Acad Sci USA 2002; 99: 3740-3745.

2. Cross SH, Bird AP. CpG islands and genes. Curr Opin Genet Dev 1995; 5 (3): 309-314.

3. Suzuki Y, Tsunoda T, Sese J, Taira H, MizushimaSugano J, Hata $H$, Ota $T$, Isogai $T$, Tanaka $T$, Nakamura Y, Suyama A, Sakaki Y, Morishita S, Okubo $\mathbf{K}$, Sugano $\mathbf{S}$. Identification and characterization of the potential promoter regions of 1031 kinds of human genes. Genome Res 2001; 11: 677-684.

4. Bird A, Tate P, Nan X, Campoy J, Meehan R, Cross S, Tweedie S, Charlton J, Macleod D. Studies of DNA methylation in animals. J Cell Sci Suppl 1995; 19: 37-39.

5. Miyamoto $\mathbf{K}$, Ushijima $\mathbf{T}$. Diagnostic and therapeutic applications of epigenetics. Jpn J Clin Oncol 2005; 35: 293-301.

6. Ohgane J, Aikawa J, Ogura A, Hattori N, Ogawa T, Shiota K. Analysis of CpG islands of trophoblast giant cells by restriction landmark genomic scanning. Dev Genet 1998; 22: 132-140.

7. Shiota K, Kogo Y, Ohgane J, Imamura T, Urano A, Nishino K, Tanaka S, Hattori N. Epigenetic marks by DNA methylation specific to stem, germ and somatic cells in mice. Genes Cells 2002; 7: 961-969.

8. Kremenskoy M, Kremenska $\mathbf{Y}$, Ohgane J, Hattori N, Tanaka S, Hashizume K, Shiota K. Genomewide analysis of DNA methylation status of $\mathrm{CpG}$ islands in embryoid bodies, teratomas and fetuses. Biochem Biophys Res Commun 2003; 311: 884-890.

9. Ohgane J, Wakayama T, Senda S, Yamazaki Y, Inoue $\mathrm{K}$, Ogura A, March J, Tanaka S, Yanagimachi R, Shiota K. The Sall3 locus is an epigenetic hotspot of aberrant DNA methylation associated with placentomegaly of cloned mice. Genes Cells 2004; 9: 253-260.

10. Strichman-Almashanu LZ, Lee RS, Onyango PO, Perlman E, Flam F, Frieman MB, Feinberg AP. A genome-wide screen for normally methylated human CpG islands that can identify novel imprinted genes. Genome Res 2002; 12: 543-554.

11. Rakyan VK, Hildmann T, Novik KL, Lewin J, Tost J, Cox AV, Andrews TD, Howe KL, Otto T, Olek A, Fischer J, Gut IG, Berlin K, Beck S. DNA methylation profiling of the human major histocompatibility complex: a pilot study for the human epigenome project. PLoS Biol 2004; 2: e405.

12. Campbell KH, McWhir J, Ritchie WA, Wilmut I. Sheep cloned by nuclear transfer from a cultured cell line. Nature 1996; 380: 64-66.

13. Wakayama T, Perry AC, Zuccotti M, Johnson KR, Yanagimachi R. Full-term development of mice from enucleated oocytes injected with cumulus cell nuclei. Nature 1998; 394: 369-374.

14. Kato Y, Tani T, Sotomaru Y, Kurokawa K, Kato J, Doguchi H, Yasue H, Tsunoda Y. Eight calves cloned from somatic cells of a single adult. Science 1998; 282: 2095-2098.

15. Polejaeva IA, Chen SH, Vaught TD, Page RL, Mullins J, Ball S, Dai Y, Boone J, Walker S, Ayares DL, Colman A, Campbell KH. Cloned pigs produced by nuclear transfer from adult somatic cells. Nature 2000; 407: 86-90.

16. Ohgane J, Wakayama T, Kogo Y, Senda S, Hattori N, Tanaka S, Yanagimachi R, Shiota K. DNA methylation variation in cloned mice. Genesis 2001; 30: 45-50.

17. Hattori N, Abe $T$, Hattori $N$, Suzuki $M$, Matsuyama T, Yoshida S, Li E, Shiota K. Preference of DNA methyltransferases for $\mathrm{CpG}$ islands in mouse embryonic stem cells. Genome Res 2004; 14: 1733-1740.

18. Anthony RV, Limesand SW, Jeckel KM. Transcriptional regulation in the placenta during normal and compromised fetal growth. Biochem Soc Trans 2001; 29: 42-48.

19. Patel OV, Yamada O, Kizaki K, Takahashi T, Imai K, Takahashi S, Izaike Y, Schuler LA, Takezawa T, Hashizume K. Expression of trophoblast cellspecific pregnancy-related genes in somaticcellcloned bovine pregnancies. Biol Reprod 2004; 70: 1114-1120.

20. Nikitenko L, Morgan G, Kolesnikov SI, Wooding FBP. Immunocytochemical and in situ hybridization studies of the distribution of calbindin D 9k in the bovine placenta throughout pregnancy. J Histochem Cytochem 1998; 46: 679-688.

21. Taniguchi Y, Itoh T, Yamada T, Sasaki Y. Genomic structure and promoter analysis of the bovine leptin gene. IUBMB Life 2002; 53: 131-135.

22. van Eijk MJ, van Rooijen MA, Modina S, Scesi $L$, Folkers G, van Tol HT, Bevers MM, Fisher SR, 
Lewin HA, Rakacolli D, Galli C, de Vaureix C, Trounson AO, Mummery CL, Gandolfi F. Molecular cloning, genetic mapping, and developmental expression of bovine POU5F1. Biol Reprod 1999; 60: 1093-1103.

23. Shiota K. DNA methylation profiles of $\mathrm{CpG}$ islands for cellular differentiation and development in mammals. Cytogenet Genome Res 2004; 105: 325-334.

24. Masuzaki H, Ogawa Y, Sagawa N, Hosoda K, Matsumoto T, Mise H, Nishimura H, Yoshimasa $Y$, Tanaka I, Mori T, Nakao K. Nonadipose tissue production of leptin: leptin as a novel placentaderived hormone in humans. Nat Med 1997; 3: 1029 1033.

25. Bajoria R, Sooranna SR, Ward BS, Chatterjee R. Prospective function of placental leptin at maternalfetal interface. Placenta 2002; 23: 103-115.

26. Ravelich SR, Shelling AN, Ramachandran A, Reddy S, Keelan JA, Wells DN, Peterson AJ, Lee RS, Breier BH. Altered placental lactogen and leptin expression in placentomes from bovine nuclear transfer pregnancies. Biol Reprod 2004; 71: 1862 1869.

27. Yokomori N, Tawata $\mathbf{M}$, Onaya T. DNA demethylation modulates mouse leptin promoter activity during the differentiation of 3T3-L1 cells. Diabetologia 2002; 45: 140-148.

28. Thomas L, Wallace JM, Aitken RP, Mercer JG, Trayhurn P, Hoggard N. Circulating leptin during ovine pregnancy in relation to maternal nutrition, body composition and pregnancy outcome. J Endocrinol 2001; 169: 465-476.

29. Bourc'his D, Le Bourhis D, Patin D, Niveleau A, Comizzoli P, Renard JP, Viegas-Pequignot E. Delayed and incomplete reprogramming of chromosome methylation patterns in bovine cloned embryos. Curr Biol 2001; 11: 1542-1546.

30. Dean W, Santos F, Stojkovic M, Zakhartchenko V, Walter J, Wolf E, Reik W. Conservation of methylation reprogramming in mammalian development: aberrant reprogramming in cloned embryos. Proc Natl Acad Sci USA 2001; 98: 1373413738.

31. Kang YK, Koo DB, Park JS, Choi YH, Chung AS, Lee KK, Han YM. Aberrant methylation of donor genome in cloned bovine embryos. Nat Genet 2001; 28: 173-177.

32. International Human Genome Sequencing Consortium. Initial sequencing and analysis of the human genome. Nature 2001; 409: 860-921.

33. Mouse Genome Sequencing Consortium. Initial sequencing and comparative analysis of the mouse genome. Nature 2002; 420: 520-562.

34. Hattori N, Nishino K, Ko YG, Hattori N, Ohgane J, Tanaka S, Shiota K. Epigenetic control of mouse Oct-4 gene expression in embryonic stem cells and trophoblast stem cells. J Biol Chem 2004; 279: $17063-$ 17069 . 